\title{
PARTNERSHIP PROGRAM SYSTEM TROUGHT SI BULE ALBINO INSTITUTIONAL BUSINESS BY MINE FIRM IN BINUANG DISTRICT KAB. TAPIN
}

\author{
Ali Khamdan \\ STIA Bina Banua Banjarmasin \\ Email: Alychamdan@yahoo.com
}

\begin{abstract}
This research explains how the partnerships system built between the comunnities arround the mine with coal mining company. Citizens fostered independence catfish farm business trought programs binuang original catfish farming system (si Bule Albinoe), the company manages CSR citizens trought funds managed by LPB Baprida. This study used descriptive qualitative approach, data are obtained primarily trought interviews with the target group, secondary data obtained from LPB Baprida. The result showed ; 1) system partnership undertaken by the company has been very precisely so as to increase income of farmers catfish. 2). a huge market demand of the catfish into opprtunities by catfish farmers in the cultivation development. 3). expand the marketing network of catfish up to the modern market. 4) in the development catfish farming is often monopolized by midlemen so that advantage by catfish farmers againt reduced. This may affect the interest of farmers in developing catfish, but the market demand for the development of this very large catfish.
\end{abstract}

Keywords : system of parterships, institutional business

\section{SISTEM KEMITRAAN PROGRAM SI BULE ALBINO MELALUI KELEMBAGAAN BISNIS OLEH PERUSAHAAN TAMBANG DI KEC. BINUANG KAB. TAPIN}

\begin{abstract}
ABSTRAK
Penelitian ini menjelaskan bagaimana sistem kemitraan yang dibangun antara masyarakat sekitar tambang dengan perusahaan pertambangan batubara. Warga dibina kemandirian bisnisnya melalui usaha peternakan lele program sistem budidaya lele asli binuang (Si Bule Albinoe), perusahaan membina warga melalui dana CSR perusahaan yang dikelola oleh LPB Baprida. Penelitian ini menggunakan pendekatan kualitatif diskriptif, data diperoleh secara primer melalui interview dengan kelompok usaha binaan, data sekunder diperoleh dari LPB Baprida. Hasil penelitian menunjukkan: 1). sistem kemitraan yang dilakukan oleh perusahaan sudah sangatlah tepat sehingga dapat membantu petani untuk meningkatkan pendapatan peternak lele. 2). Permintaan pasar yang besar terhadap ikan lele menjadi peluang oleh peternak lele dalam pengembangan budidaya tersebut. 3). Memperluas jaringan pemasaran ikan lele hingga ke pasar modern. 4) dalam pengembangan budidaya ikan lele masih sering dimonopoli oleh tengkulak sehingga keuntungan oleh petani terhadap ikan lele berkurang. Hal ini dapat mempengaruhi minat petani dalam pengembangan ikan lele. Namun permintaan pasar terhadap pengembangan ikan lele ini sangatlah besar.
\end{abstract}

Kata kunci : sistem kemitraan, kelembagaan bisnis 


\section{PENDAHULUAN}

Mayoritas mata pencaharian penduduk Kabupaten Tapin adalah bertani, namun seiring tumbuh kembangnya pertambangan di daerah Tapin sehingga lahan yang digunakan untuk bertani menjadi terbatas. Meskipun memiliki lahan yang dapat digunakan untuk bertani, namun mayoritas lahan yang digunakan adalah lahan gambut dan lebak sehingga kualitas panen yang didapat masih perlu diperhatikan.

Di sisi lain isu ketenagakerjaan juga menjadi fokus utama dalam keberlangsungan perusahaan. Banyak masyarakat yang melakukan demo terkait ketenagakerjaan, mereka menuntut diberikan lapangan pekerjaan di perusahaan tambang untuk meningkatkan taraf hidup dan perekonomian mereka. Hal ini cukup sulit direalisasikan mengingat keterbatasan kompetensi mereka dan tidak terpenuhinya kualifikasi untuk dapat lolos menjadi karyawan perusahaan tambang.

Besarnya nilai komplain dan keterbatasan lahan yang digunakan untuk bertani inilah menjadi dasar penulis untuk mencari solusi yang tepat untuk melakukan pengembangan ekonomi di daerah ring 1 perusahaan tambang PT. Kalimantan Prima Persada (KPP). Melalui program Income Generating Activity (IGA), penulis membuat program Si Bule Albino ( $\mathrm{Si}$ Budidaya Lele Asal Binoeang). Pelaksanaan program ini meliputi mapping, pelatihan, bantuan pemasaran hingga variasi produk lele.

Diharapkan program ini dapat menekan angka ketergantungan kepada perusahaan tambang selain itu untuk kedepannya dapat menjadi sentra perikanan di daerah Binuang serta meningkatkan perekonomian masyarakat sehingga mereka dapat menjadi masyarakat yang mandiri. Target selanjutnya program budidaya lele ini akan bekerjasama dengan Lembaga Keuangan Mikro Syariah (LKMS) Berkah Banua yang juga merupakan salah satu program CSR KPP dalam hal pembiayaan sehingga modal untuk penjualan dapat lebih besar lagi mengingat permintaan pasar dari pasar tradisional dan pasar modern yang sangat tinggi.

Berdasarkan hasil kajian lebih lanjut oleh Kementrian Kelautan dan Perikanan, Hasil produksi perikanan Kalimantan Selatan secara umum masih banyak diserap untuk kebutuhan domestik sehingga menyebabkan usaha pemasaran ekspor hasil perikanan masih belum berkembang secara baik. Permasalahan umum sektor perikanan di Kalimantan Selatan adalah kurang optimalnya pemanfaatan lahan khususnya perairan umum, selain itu juga lemahnya penerapan teknologi budidaya sehingga menghambat pengembangan budidaya perikanan.

(http://www.sidik.litbang.kkp.go.id/index.php/se archkatalog/byId/13309).

Minat dan kebutuhan masyarakat Binuang dan sekitarnya pun ternyata cukup tinggi untuk perikanan. Hal ini dibuktikan dengan menjamurnya rumah makan dan warungwarung yang menyediakan variasi makanan ikan sehingga KPP melihat peluang pemasaran untuk para petani lele masih besar dan dapat dijadikan pekerjaan tetap yang menjanjikan. Terlihat bahwa kebutuhan dari pasokan ikan lele untuk di daerah Tapin sebanyak 3.000$4.000 \mathrm{~kg}$ per bulannya. Oleh karenanya peluang menjadi pemasok ikan lele sangat terbuka luas.

Adapun petani-petani yang telah menjadi binaan PT. KPP awalnya terdiri dari 5 kelompok yang akhirnya berkembang hingga mencapai 8 kelompok. Adapun nama petani dan kelompok budidaya ikan lele tersebut ialah sebagai berikut: 
Tabel. Kelompok Binaan Budi daya Ikan Lele

\begin{tabular}{|c|c|c|c|c|c|c|c|c|}
\hline No & Nama Petani & Desa & \begin{tabular}{|c|} 
Kecamata \\
$\mathbf{n}$
\end{tabular} & $\begin{array}{c}\text { Nama } \\
\text { Kelompok }\end{array}$ & $\begin{array}{c}\text { Awal } \\
\text { Budidaya }\end{array}$ & Satuan & Pekerjaan Tetap & $\begin{array}{c}\text { Pendapatan } \\
\text { Awal }\end{array}$ \\
\hline 1 & Haris Sa'dilah & Desa Kelumpang & Bungur & Mina Karya & 3,000 & Ekor & $\begin{array}{l}\text { Petani Budidaya } \\
\text { Ikan Tawar }\end{array}$ & $2,000,000$ \\
\hline 2 & Saifudin & Desa Kelumpang & Bungur & UPP Tapin & 6,000 & Ekor & $\begin{array}{l}\text { Penyuluh } \\
\text { Perikanan }\end{array}$ & $2,500,000$ \\
\hline 3 & Tukiman & Desa Harapan Masa & apin Selata & $\begin{array}{c}\text { Sumber } \\
\text { Berkat }\end{array}$ & 3,000 & Ekor & $\begin{array}{l}\text { Petani Budidaya } \\
\text { Ikan Tawar }\end{array}$ & $1,750,000$ \\
\hline 4 & Muhdad & Desa Pulau Pinang & Binuang & Suka Maju & 10,000 & Ekor & Pekebun Karet & $4,000,000$ \\
\hline 5 & M. Fathul Mu'min & $\begin{array}{l}\text { Desa Pulau Pinang } \\
\text { Utara }\end{array}$ & Binuang & $\begin{array}{l}\text { Harapan } \\
\text { Bersama }\end{array}$ & 2,000 & Ekor & Pekebun Karet & $3,500,000$ \\
\hline 6 & Taufik & Desa Pulau Pinang & Binuang & Suka Maju & 8,000 & Ekor & \begin{tabular}{|l|} 
Karyawan Tambang \\
Binuang
\end{tabular} & $3,700,000$ \\
\hline 8 & Yusuf & Karangan Putih & Binuang & $\begin{array}{c}\text { Maju Bersama } \\
\text { Siderejo }\end{array}$ & 18,000 & Ekor & $\begin{array}{l}\text { OB LPB dan Petani } \\
\text { Ikan }\end{array}$ & $2,500,000$ \\
\hline 9 & Hakim & $\begin{array}{l}\text { Tinggiran Rt. } 05 \text { Rw. } \\
03 \text { Desa Pulau } \\
\text { Pinang Utara }\end{array}$ & Binuang & $\begin{array}{l}\text { Harapan } \\
\text { Bersama }\end{array}$ & 6,000 & Ekor & $\begin{array}{l}\text { Pekebun dan } \\
\text { Peternak Bebek }\end{array}$ & $3,500,000$ \\
\hline
\end{tabular}

Berdasarkan uraian di atas, penulis tertarik untuk mengkaji penulisan artikel dengan judul:

"Sistem Kemitraan Program Si Bule Albino Melalui Kelembagaan Bisnis Oleh Perusahaan Tambang di Kec. Binuang Kab. Tapin"

Penulis memilih perusahaan tersebut karena penulis pernah melakukan kunjungan dan pengamatan sehingga penulis tertarik dalam pengembangan pola pikir dan juga kajian bisnis masyarakat di sekitar tambang batubara.

\section{Perumusan Masalah}

1 Bagaimana penerapan sistem kemitraan Program Si Bule Albino (Si Budidaya Lele Asal Binoeang) PT. KPP diwilayah Kec. Binuang?

2 Kendala-kendala apa saja yang dihadapi dalam penerapan kemitraan Program Si Bule Albino PT. KPP di wilayah Kecamatan Binuang?

3 Bagaimana upaya yang harus dilakukan untuk mengatasi kendala kemitraan Program Si Bule Albino PT. KPP di wilayah Kecamatan Binuang?

\section{Tujuan Penelitian}

Dari rumusan masalah diatas, maka tujuan penelitian ini adalah sebagai berikut :

1. Untuk mengetahui penerapan sistem kerjasama kemitraan Si Bule Albino PT. KPP di wilayah Kecamatan Binuang.

2. Ingin mengetahui kendala-kendala yang dihadapi dalam sistem kemitraan Si Bule Albino PT. KPP di wilayah Kecamatan Binuang.

3. Ingin memberikan masukan tentang upaya yang harus dilakukan dalam mengatasi kendala-kendala Program Si Bule Albino PT. KPP.

\section{Manfaat Hasil Penelitian}

1. Aspek Akademis

Dapat memberikan masukkan dalam pengembangan ilmu kebijakan bisnis dan sebagai dasar untuk penelitian yang relevan selanjutnya.

2. Aspek Praktis

Sebagai sumbangan pemikiran dan informasi kemitraan dalam dunia bisnis Usaha Mikro Kecil dan Menengah, yang 
dapat dimanfaatkan sebagai bahan referensi dan studi perbandingan.

\section{TINJAUAN PUSTAKA}

\section{Pengertian Sistem dan Kemitraan Sistem}

Pengertian sistem menurut beberapa pakar antara lain adalah sebagai berikut:

"Sistem adalah elemen-elemen yang saling berhubungan membentuk suatu kesatuan atau organisasi”. (Amsyah 2005:4).

Adapun pegertian sistem menurut Jogiyanto:

"Suatu sistem adalah suatu jaringan kerja dari prosedur-prosedur yang saling berhubungan, berkumpul bersama-sama untuk melakukan suatu kegiatan atau untuk menyelesaikan suatu sasaran yang tertentu". (Jogiyanto 2005:1).

Dari pengertian diatas dapat diambil suatu kesimpulan bahwa suatu sistem merupakan elemen yang saling berkaitan dan saling mempengaruhi dalam melakukan kegiatan bersama untuk mencapai suatu tujuan tertentu.

\section{Kemitraan}

Kemitraan menurut Kamus Besar Bahasa Indonesia (2005:74): Arti kata mitra adalah teman; sahabat, kawan kerja, pasangan kerja, rekan. Kemitraan pada esensinya adalah dikenal dengan istilah gotong royong atau kerjasama sebagai mitra dari berbagai pihak, baik secara individual maupun kelompok.

Berdasarkan pendapat Hafsah (2005: 43):

"Kemitraan adalah suatu strategi bisnis yang dilakukan oleh dua pihak atau lebih dalam jangka waktu tertentu untuk meraih keuntungan bersama dengan prinsip saling membutuhkan dan saling membesarkan. Karena merupakan strategi bisnis maka keberhasilan kemitraan sangat ditentukan oleh adanya kepatuhan diantara yang bermitra dalam menjalankan etika bisnis".
Lebih lanjut, Anoraga (2007: 232), Kemitraan merupakan suatu bentuk jalinan kerjasama dari dua atau lebih pelaku usaha yang saling menguntungkan.Terjadinya kemitraan adalah bila ada keinginan yang sama untuk saling mendukung dan saling melengkapi dalam upaya mencapai tujuan bersama. Kemitraan usaha ini dilakukan antara usaha kecil dengan sektor usaha besar. Dengan adanya kemitraan ini, usaha kecil diharapkan dapat hidup berdampingan dan sejajar dengan usaha besar.

Menurut Notoatmodjo (2005), kemitraan adalah suatu kerja sama formal antara individuindividu, kelompok-kelompok atau organisasiorganisasi untuk mencapai suatu tugas atau tujuan tertentu.

Dalam Ketentuan Umum Peraturan Pemerintah Nomor. 44 Tahun 1997 terutama dalam Pasal 1 menyatakan bahwa : "Kemitraan adalah kerjasama usaha antara usaha kecil dengan usaha menengah dan atau dengan usaha besar dengan memperlihatkan prinsip saling memerlukan, saling memperkuat dan saling menguntungkan".

Dalam UU No.9 Tahun 1995 Tentang Usaha Kecil , konsep kemitraan dirumuskan dalam pasal 26 sebagai berikut :

a) Usaha Menengah dan Usaha Besar melaksanakan hubungan kemitraan dengan usaha kecil, baik yang memiliki maupun yang tidak memiliki keterkaitan usaha.

b) Pelaksanaan hubungan kemitraan sebagaimana dimaksud dalam ayat (1) diupayakan ke arah terwujudnya keterkaitan usaha.

c) Kemitraan dilaksanakan dengan disertai pembinaan dan pengembangan dalam salah satu atau lebih bidang produksi dan pengolahan, pemasaran, permodalan, sumber daya manusia, dan teknologi.

d) Dalam melaksanakan hubungan ke dua belah pihak mempunyai kedudukan hukum yang setara. 


\section{Prinsip Kemitraan}

Terdapat 3 prinsip kunci yang perlu dipahami dalam membangun suatu kemitraan oleh masing-masing naggota kemitraan yaitu:

1 Prinsip Kesetaraan (Equity) Individu, organisasi atau institusi yang telah bersedia menjalin kemitraan harus merasa sama atau sejajar kedudukannya dengan yang lain dalam mencapai tujuan yang disepakati.

2 Prinsip Keterbukaan

Keterbukaan terhadap kekurangan atau kelemahan masing-masing anggota serta berbagai sumber daya yang dimiliki. Semua itu harus diketahui oleh anggota lain. Keterbukaan ada sejak awal dijalinnya kemitraan sampai berakhirnya kegiatan. Dengan saling keterbukaan ini akan menimbulkan saling melengkapi dan saling membantu diantara golongan (mitra).

3 Prinsip Azas manfaat bersama (mutual benefit)

Individu, organisasi atau institusi yang telah menjalin kemitraanmemperoleh manfaat dari kemitraan yang terjalin sesuai dengan kontribusi masing-masing. Kegiatan atau pekerjaan akan menjadi efisien dan efektif bila dilakukan bersama. (Ditjen P2L \& PM, 2005)

\section{Langkah-langkah Kemitraan}

Kemitraan memberikan nilai tambah kekuatan kepada masing-masing sektor untuk melaksanakan visi dan misinya. Namun kemitraan juga merupakan suatu pendekatan yang memerlukan persyaratan, untuk itu diperlukan langkah-langkah tahapan sebagai berikut:

1) Pengenalan masalah

2) Seleksi masalah

3) Melakukan identifikasi calon mitra dan pelaku potensial melalui suratmenyurat, telepon, kirim brosur, rencana kegiatan, visi, misi, AD/ART.
4) Melakukan identifikasi peran mitra/jaringan kerjasama antar sesama mitra dalam upaya mencapai tujuan, melalui: diskusi, forum pertemuan,kunjungan kedua belah pihak, dll

5) Menumbuhkan kesepakatan yang menyangkut bentuk kemitraan, tujuan dan tanggung jawab, penetapan rumusan kegiatan memadukan sumberdaya yang tersedia di masing-masing mitra kerja, dll. Kalau ini sudah ditetapkan, maka setiap pihak terbuka kesempatan untuk melaksanakan berbagai kegiatan yang lebih bervariasi sepanjang masih dalam lingkup kesepakatan.

6) Menyusun rencana kerja: pembuatan POA penyusunan rencana kerja dan jadwal kegiatan, pengaturan peran, tugas dan tanggung jawab.

7) Melaksanakan kegiatan terpadu: menerapkan kegiatan sesuai yang telah disepakati bersama melalui kegiatan, bantuan teknis, laporan berkala, dll.

8) Pemantauan dan evaluasi

\section{Model-model Kemitraan dan Jenis Kemitraan}

Menurut Beryl Levinger dan Jean Mulroy (2005), ada empat jenis atau tipe kemitraan yaitu:

\section{Potential Partnership}

Pada jenis kemitraan ini pelaku kemitraan saling peduli satu sama lain tetapi belum bekerja bersama secara lebih dekat.

\section{Nascent Partnership}

Kemitraan ini pelaku kemitraan adalah partner tetapi efisiensi kemitraan tidak maksimal

\section{Complementary Partnership}

Pada kemitraan ini, partner/mitra mendapat keuntungan dan pertambahan pengaruh melalui perhatian yang besar pada ruang lingkup aktivitas yang tetap dan relatif 
terbatas seperti program delivery dan resource mobilization.

\section{Synergistic Partnership}

Kemitraan jenis ini memberikan mitra keuntungan dan pengaruh dengan masalah pengembangan sistemik melalui penambahan ruang lingkup aktivitas baru seperti advokasi dan penelitian.

\section{Unsur-Unsur Kemitraan}

Pada dasarnya kemitraan itu merupakan suatu kegiatan saling menguntungkan dengan berbagai macam bentuk kerjasama dalam menghadapi dan memperkuat satu sama lainnya.

Kemitraan itu mengandung beberapa unsur pokok yang merupakan kerjasama usaha dengan prinsip saling menguntungkan, saling memperkuat dan saling memerlukan.

1 Kerjasama Usaha

Dalam konsep kerjasama usaha melalui kemitraan ini, jalinan kerjasama yang dilakukan antara usaha besar atau menengah dengan usaha kecil didasarkan pada kesejajaran kedudukan atau mempunyai derajat yang sama terhadap kedua belah pihak yang bermitra. Ini berarti bahwa hubungan kerjasama yang dilakukan antara pengusaha besar atau menengah dengan pengusaha kecil mempunyai kedudukan yang setara dengan hak dan kewajiban timbal balik sehingga tidak ada pihak yang dirugikan, tidak ada yang saling mengeksploitasi satu sama lain dan tumbuh berkembangnya rasa saling percaya di antara para pihak dalam mengembangkan usahanya.

2 Antara Pengusaha Besar atau Menengah Dengan pengusaha Kecil

Dengan hubungan kerjasama melalui kemitraan ini diharapkan pengusaha besar atau menengah dapat menjalin hubungan kerjasama yang saling menguntungkan dengan pengusaha kecil atau pelaku ekonomi lainnya, sehingga pengusaha kecil akan lebih berdaya dan tangguh didalam berusaha demi tercapainya kesejahteraan.

3 Pembinaan dan Pengembangan

Pada dasarnya yang membedakan hubungan kemitraan dengan hubungan dagang biasa oleh pengusaha kecil dengan pengusaha besar adalah adanya bentuk pembinaan dari pengusaha besar terhadap pengusaha kecil atau koperasi yang tidak ditemukan pada hubungan dagang biasa. Bentuk pembinaan dalam kemitraan antara lain pembinaan didalam mengakses modal yang lebih besar, pembinaan manajemen usaha, pembinaan peningkatan Sumber Daya Manusia (SDM), pembinaan manajemen produksi, pembinaan mutu produksi serta menyangkut pula pembinaan didalam pengembangan aspek institusi kelembagaan, fasilitas alokasi serta investasi.

\section{Prinsip Saling Memerlukan, Saling Memperkuat dan Saling Menguntungkan}

\section{Prinsip Saling Memerlukan}

Dalam kemitraan, perusahaan besar dapat menghemat tenaga dalam mencapai target tertentu dengan menggunakan tenaga kerja yang dimiliki oleh perusahaan yang kecil. Sebaliknya perusahaan yang lebih kecil, yang umumnya relatif lemah dalam hal kemampuan teknologi, permodalan dan sarana produksi melalui teknologi dan sarana produksi yang dimiliki oleh perusahaan besar. Dengan demikian sebenarnya ada saling memerlukan atau ketergantungan diantara kedua belah pihak yang bermitra.

\section{Prinsip Saling Memperkuat}

Dalam kemitraan usaha, sebelum kedua belah pihak memulai untuk bekerjasama, maka pasti ada sesuatu nilai tambah yang ingin diraih oleh masing-masing pihak yang bermitra. Nilai tambah ini selain diwujudkan dalam bentuk nilai ekonomi seperti peningkatan modal dan keuntungan, perluasan pangsa pasar, tetapi juga ada nilai tambah yang non ekonomi seperti peningkatan kemampuan manajemen, 
penguasaan teknologi dan kepuasan tertentu. Keinginan ini merupakan konsekuensi logis dan alamiah dari adanya kemitraan.

\section{Prinsip Saling Menguntungkan}

Salah satu maksud dan tujuan dari kemitraan usaha adalah "win-win solution partnership" kesadaran dan saling menguntungkan. Pada kemitraan usaha terutama sekali terhadap hubungan timbal balik, bukan seperti kedudukan antara buruh dan majikan, atau terhadap atasan kepada bawahan sebagai adanya pembagian resiko dan keuntungan proporsional, disinilah letak kekhasan dan karakter dari kemitraan usaha tersebut.

\section{Tujuan Kemitraan}

Tujuan kemitraan meliputi beberapa aspek (Hafsah, 2005 : 54), antara lain yaitu :

1 Tujuan dari Aspek Ekonomi

Dalam kondisi yang ideal, tujuan yang ingin dicapai dalam pelaksanaan kemitraan secara lebih kongkrit yaitu :

a) Meningkatkan pendapataan usaha kecil dan masyarakat

b) Meningkatkan perolehan nilai tambah bagi pelaku kemitraan

c) Meningkatkan pemerataan dan pemberdayaan masyarakat dan usaha kecil

d) Meningkatkan pertumbuhan ekonomi pedesaan, wilayah dan nasional

e) Memperluas kesempatan kerja

f) Meningkatkan ketahanan ekonomi nasional

2 Tujuan dari Aspek Sosial dan Budaya

Kemitraan usaha dirancang sebagai bagian dari upaya pemberdayaan usaha kecil. Pengusaha besar berperan sebagai faktor percepatan pemberdayaan usaha kecil sesuai kemampuan dan kompetensinya dalam mendukung mitra usahanya menuju kemandirian usaha, atau dengan perkataan lain kemitraan usaha yang dilakukan oleh pengusaha besar yang telah mapan dengan pengusaha kecil sekaligus sebagai tanggung jawab sosial pengusaha besar untuk ikut memberdayakan usaha kecil agar tumbuh menjadi pengusaha yang tangguh dan mandiri. Adapun sebagai wujud tanggung jawab sosial itu dapat berupa pemberian pembinaan dan pembimbingan kepada pengusaha kecil, dengan pembinaan dan bimbingan yang terus menerus diharapkan pengusaha kecil dapat tumbuh dan berkembang sebagai komponen ekonomi yang tangguhdan mandiri.

3 Tujuan dari Aspek Teknologi

Sehubungan dengan keterbatasan khususnya teknologi pada usaha kecil, maka pengusaha besar dalam melaksanakan pembinaan dan pengembangan terhadap pengusaha kecil meliputi juga memberikan bimbingan teknologi. Teknologi dilihat dari arti kata bahasannya adalah ilmu yang berkenaan dengan teknik. Oleh karena itu, bimbingan teknologi yang dimaksud adalah berkenaan dengan teknik berproduksi untuk meningkatkan produktivitas dan efisiensi.

4 Tujuan dari Aspek Manajemen

Manajemen merupakan proses yang dilakukan oleh satu atau lebih individu untuk mengkoordinasikan berbagai aktivitas lain untuk mencapai hasil-hasil yang tidak bisa dicapai apabila satu individu bertindak sendiri. Ada 2 (dua) hal yang menjadi pusat perhatian yaitu :

a. Peningkatan produktivitas individu yang melaksanakan kerja.

b. Peningkatan produktivitas organisasi di dalam kerja yang dilaksanakan. 


\section{METODE PENELITIAN}

\section{Jenis Penelitian}

Penelitian ini bermaksud untuk menganalisis dan memperoleh gambaran (deskripsi) sistem kemitraan yang dilakukan PT. KPP melalui Program Si Bule Albino Melalui Kelembagaan Bisnis di Kecamatan Binuang Kabupaten Tapin. Dengan demikian metode yang tepat adalah dengan mengacu pada konsep penelitian kualitatif, karena lebih mudah bagi peneliti untuk dapat melakukan pencarian (discovery) melalui key informan yang ditetapkan.

\section{Jenis dan Sumber Data}

\section{Jenis Data}

a. Data Kualitatif

Data kualitatif adalah data yang tidak diwujudkan dalam angka-angka melainkan penjelasan yang menggambarkan keadaan perusahaan atau lembaga.

b. Data Kuantitatif

Data kuantitaitif adalah data yang diwujudkan dalam angka-angka yang menggambarkan statistik operasional atau keadaan perusahaan/lembaga.

\section{Sumber Data}

a. Data primer adalah data yang dikumpulkan oleh penulis secara langsung dari sumber yang menjadi objek penelitiannya.

b. Data sekunder adalah data yang diperoleh berasal dari dokumen dokumen perusahaan/lembaga itu sendiri.

\section{Teknik Pengumpulan Data}

Data yang digunakan dalam penelitian ini merupakan data primer dan data sekunder. Data primer adalah data yang didapat langsung dari sumber pertama dan data sekunder adalah data yang didapat berasal dari dokumen-dokumen perusahaan atau lembaga itu sendiri. Pengumpulan data ini dilakukan dengan cara:

1. Library Research (Riset Kepustakaan) yaitu penelitian yang dilakukan dengan cara mengumpulkan data-data dan bahan-bahan dari beberapa literatur yang ada hubungannya dengan permasalahan yang dibahas.

2. Field Research (Riset Lapangan) yaitu mengumpulkan data dengan cara terjun langsung ke tempat obyek penelitian. Datadata tersebut diperoleh dengan cara:

a. Wawancara (Interview) yaitu mengumpulkan informasi dengan media Tanya jawab secara langsung dengan responden.

b. Pengamatan Langsung (Observasi) yaitu pengumpulan data dengan mengamati secara langsung pada objek yang diteliti untuk memperoleh gambaran yang lebih jelas tentang permasalahan yang berkenaan dengan perilaku manusia, proses kerja dan gejala - gejala alam.

c. Dokumentasi yaitu teknik mengumpulkan, meneliti mempelajari dokumen, catatan dan laporan-laporan yang berhubungan dengan masalah yang akan diteliti dari dokumendokumen yang dimiliki oleh PT. KPP sehingga dapat membantu proses tersusunnya skripsi yang penulis lakukan dan selesai sesuai dengan waktu yang telah ditentukan.

Data yang diperoleh akan diolah agar dapat disajikan dalam bentuk yang lebih mudah dibaca dan dikemukankan sebagaimana adanya sehingga tidak bertentangan dengan ketentuan yang berlaku. Pengolahan data untuk penelitian ini menggunakan teknik analisis statistik deskriptif. Statistik deskriptif adalah statistika yang berkenaan dengan metode atau cara mendeskripsikan, menjabarkan, menggambarkan atau menguraikan data yang mengacu pada 
bagaimana menata, menyajikan, dan meneganalisis data dalam bentuk tulisan.

\section{HASIL PENELITIAN DAN PEMBAHASAN}

\section{Penerapan Sistem Kemitraan}

Dalam hal ini KPP bersama dengan LPB menyusun program untuk diterapkan demi mencapai tujuannya, program kerja tersebut adalah sebagai berikut:

1. Mapping kelompok petani lele

Mapping ini dilakukan sebagai bentuk kelompok percontohan dan sebagai role model untuk masyarakat lainnya agar dapat memotivasi masyarakat lainnya agar dapat menjadi petani lele yang sukses. Hal ini juga dilakukan agar KPP dapat fokus dalam melakukan monitoring dan evaluasi para petani lele

2. Pemberian Pelatihan

Berbagai macam pelatihan dilakukan agar kompetensi dari para petani lele dapat meningkat dari segi perawatan, pembuatan pakan, pembukuan hingga pemasaran. Pelatihan ini dilakukan oleh KPP bekerjasama dengan LPB dan Dinas Perikanan

3. Program demplot budidaya lele

Pembuatan kolam tempat budidaya ikan lele di tempat petani dipilih oleh perusahaan dengan dasar berada di area ring 1 perusahaan. Untuk Proses awal diberikan bantuan kepada 5 kelompok percontohan. Selanjutnya setelah pengolahan kolam dan air yang telah melalui proses pengendapan yang bertujuan menumbuhkan plankton-plankton sebagai pakan awal bibit yang akan dilepas dikolam. Bibit dibagikan kepada kelompok petani, sebagai percobaan awal masingmasing kelompok diberikan 3.000 ekor bibit.

4. Pemasaran hasil panen

Pemasaran hasil panen dibantu oleh team LPB. Pada tahun 2014 penyerapan pasar banyak diserap oleh pasar tradisional

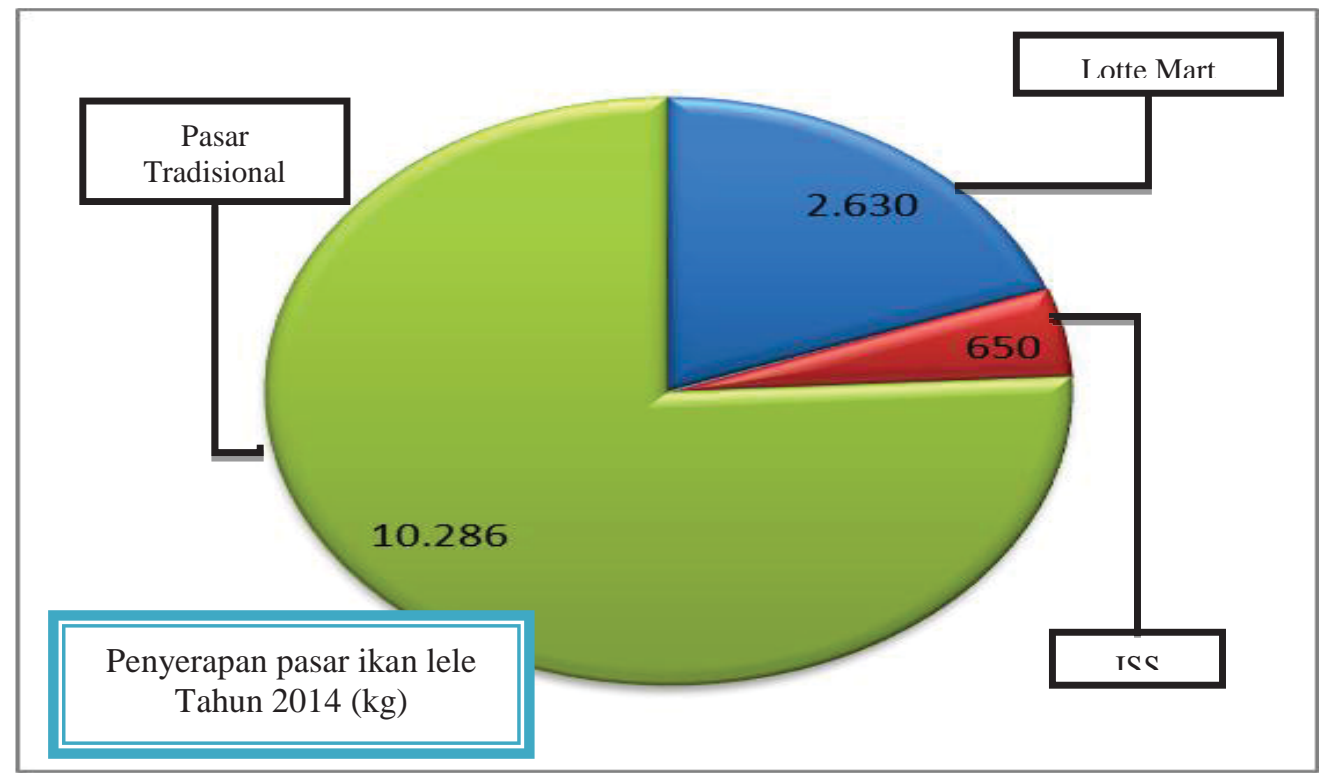


Indikator keberhasilan dari segi pemasaran adalah hasil panen ikan lele yang ada dapat menembus pasar Lotte Mart dan Catering ISS. Karena permintaan yang sangat tinggi dan kualitas yang memang sudah diakui dan lolos kriteria Lotte Mart, petani binaan KPP kini masih terus dituntut untuk dapat memenuhi permintaan pasar Lotte Mart. Tidak jauh berbeda dari Lotte Mart, kini ISS pun banyak bergantung dari petani binaan KPP untuk memenuhi kebutuhan ISS.

Asal mula kerjasama dengan pihak Lotte Mart berawal dari kegiatan temu pasar bersama petani-petani yang dilakukan oleh KPP. Pertemuan dilanjutkan ke Lotte Mart yang oleh Pihak KPP untuk membahas langkah awal dan apa saja yang menjadi kebutuhan oleh Lotte Mart. Pada awal kerjasamanya para petani melalui KPP dan LPB melakukan pembelian putus, Lotte mart melakukan pembayaran cash ketika barang telah diterima oleh pihak Lotte Mart. Setelah dua bulan kerjasama berjalan para petani diminta oleh Pihak Lotte Mart untuk mengajukan sistem kerjasama dan melakukan pendaftaran sebagai vendor resmi Lotte Mart. Pada bulan keempat permintaan pun dilakukan dengan menggunakan PO. Kita harus dapat berbangga diri karena Lotte Mart dengan Petani binaan KPP berhasil melakukan penandatangangan MoU dalam hal pemasokan ikan lele dan holtikultura

5. Perolehan Laba

Indikator keberhasilan program IGA adalah adanya peningkatan pendapatan dari para peserta program.

\section{Kendala Penerapan Sistem Kemitraan}

Dalam hal penerapan sIstem kemitraan PT. KPP dalam melaksanakan program Si Bule Albino (Si Budidaya Lele Asal Binoang) juga mendapatkan kendala-kendala yang mempengaruhi dalam pengembangan budidaya ikan lele ialah sebagai berikut :

1 Maping Kelompok Tani

Dalam menganalasi kelompok tani ikan lele PT. KPP juga mendapatkan kendala yaitu dari SDM yang terbatas serta tingkat keterampilan yang kurang.

2 Pemberian Pelatihan

Kendala yang dihadapi dalam pemberian pelatihan ialah kemampuan daya tangkap petani terhadap materi yang di berikan oleh instrukture serta keterbatasan waktu yang terbatas dalam pemberian materi.

\section{Program Demplot Budidaya Ikan Lele}

Berbagai macam kendala yang dihadapi dalam demplot budidaya ikan lele ini ialah dari hal yang teknis sampai dengan kepercayaan diri oleh petani itu sendiri. Adapun kendala yang dihadapi oleh petani ialah sebagai berikut:

\section{Pemasaran hasil panen}

Kendala dalam pemasaran hasil panen ini ialah monopoli harga yang di kuasai oleh tengkulak. PT. KPP berupaya akan membantu petani tanpa juga harus bersinggungan dengan tengkulak ialah dengan memberikan jaringan pemasaran terhadap petani. Harga jual ikan lele yang dibeli oleh tengkulak terhadap petani ialah Rp. 11.000/Kg ini sangat berbeda dengan harga jual yang ada dipasaran sebesar Rp. 18.000 s/d Rp. 20.000 per kg. Sedangkan biaya operasional yang dikeluarkan oleh petani ikan lele dari awal budidaya (Pembuatan Kolam, Penebaran Bibit, Pemberian Pakan dan Penyusutan) itu berkisar Rp. 10.000,- Per Kg. Perhitungan itu sangatlah minim apabila daya jual ikan lele dari petani ke tengkulak sebesar Rp. 11.000,- Per Kg. Hal ini lah PT. KPP akan berupaya membantu pemasaran ke pasar modern dengan memfasilitasi para petani ikan lele. 


\section{Perolehan Laba}

Adapun Perolehan laba yang didapatkan oleh petani kan lele dapat dilihat pada grafik pendapatan ialah sebagai berikut:

Grafik. Pertumbuhan Laba Kelompok Petani Ikan Lele

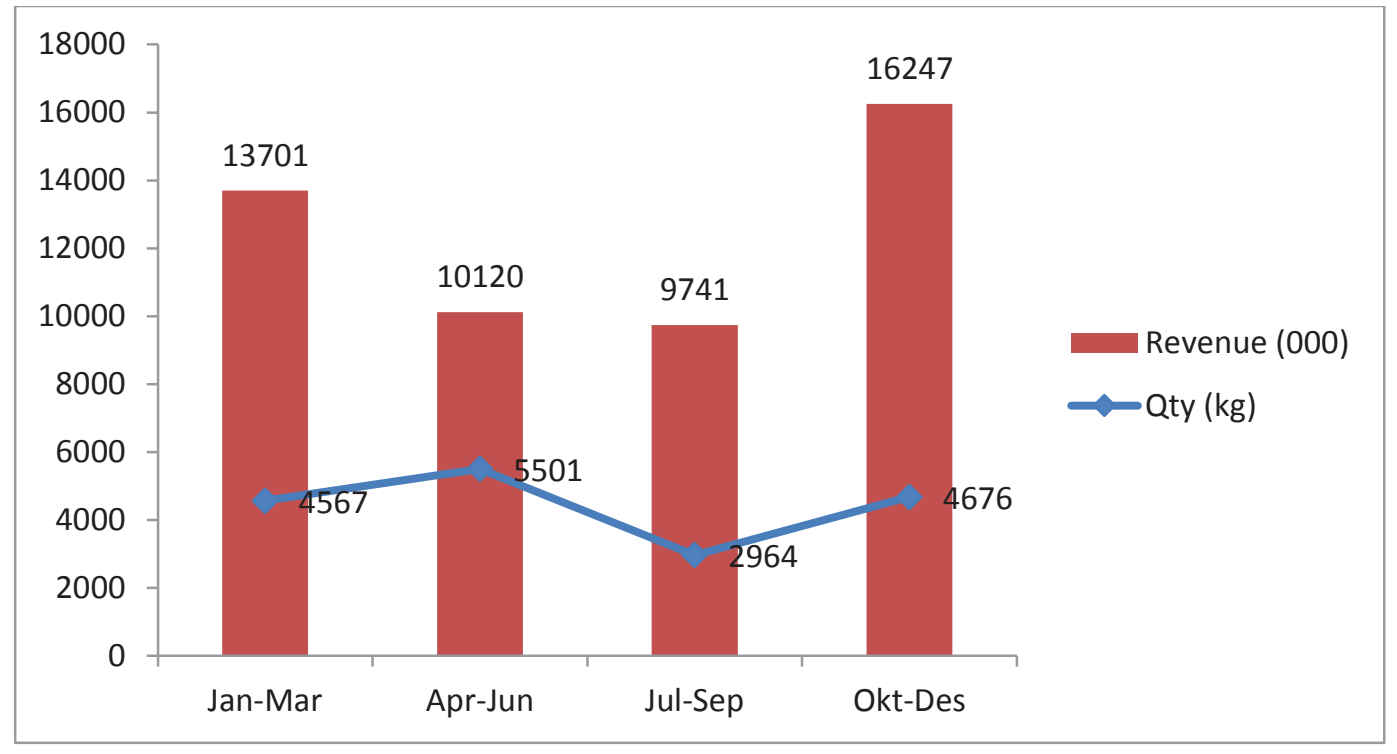

Terjadi penurunan dalam segi revenue dan permintaan, ini dikarenakan adanya pasokan lele beku dari Jawa yang masuk ke wilayah Banjarmasin dengan harga yang rendah. Hal ini mengakibatkan masyarakat beralih ke lele beku. Oleh karenanya KPP memfasilitasi para petani untuk mengadakan temu pasar dengan demikian para petani dapat duduk bersama untuk melakukan evaluasi harga pasaran untuk ikan lele. Di bulan Oktober permintaan dan harga kembali normal, konsumen menyadari kualitas lele beku tidak dapat menandingi kualitas lele yang segar.

\section{Alternatif Solusi}

Program Budidaya lele ini mengajarkan kepada masyarakat bahwa dengan segala usaha dan niat juga tekad yang kuat segala sesuatu pasti dapat dilaksanakan dengan baik dan dapat mencapai hasil yang memuaskan. Hal ini dapat mengubah paradigma masyarakat bahwa perusahaan bukan hanya satu-satunya tempat untuk mencari nafkah, masih ada alternatif usaha lainnya yang dapat dijadikan mata pencaharian yang menjanjikan. Budidaya ikan lele juga bukan menjadi hal yang sulit untuk saat ini, banyak pelatihan juga metode-metode yang dapat diperoleh sehingga dapat menghasilkan suatu hasil produk yang baik dan sesuai kualitas mutu ekspor. Setiap produk dituntut untuk memiliki keunikan, hal inilah yang mendorong petani untuk terus memiliki kreatifitas. Dengan adanya keunikan dalam produk dan juga quality kontrol yang baik sebuah produk akan mendapatkan nilai jual yang tinggi.

Adapun alternatif solusi yang diberikan oleh penulis kepada perusahaan guna mengembangkan ikan lele ialah mulai dibentuknya Lembaga Pembiayaan yang ada. Dan informasi yang diberikan oleh PT. KPP bahwasanya telah ada LKMS Berkah Banua yang telah dibuat oleh perusahaan. Hal ini seharusnya bisa menjadi langkah cepat perusahaan untuk dapat mengembangkan budidaya ikan lele. Diharapkan kerjasama 
petani dengan LKMS Berkah Banua ini dapat membuat petani ikan lele menjadi mandiri serta lebih aktif dalam pengembangan budidaya ikan lele. Serta pengembangan ikan lele ini juga harus memikirkan hasil yang berupa produk ikan lele tersebut guna dapat meningkatkan harga jual. Sebelumnya lele sudah dapat dibuat menjadi Abon lele. Penulis memberikan masukan ialah pembuatan kemasan untuk abon lele, pemberian label B.pom dan pemberian label halal.

\section{SIMPULAN}

1 Dalam pengembangan budidaya ikan lele masih sering dimonopoli oleh tengkulak sehingga keuntungan oleh petani terhadap ikan lele sangatlah minim. Hal ini dapat mempengaruhi minat petani dalam pengembangan ikan lele. Namun permintaan pasar terhadap pengembangan ikan lele ini sangatlah besar

2 Sistem kemitraan yang dilakukan oleh perusahaan sudah sangatlah tepat sehingga dapat membantu petani untuk meningkatkan pendapatan petani ikan lele. Serta dapat memperluas jaringan pemasaran hingga ke pasar modern.

3 Permintaan pasar yang bersar terhadap ikan lele seharusnya menjadi peluang oleh petaniikan lele dalam pengembangan budidaya tersebut.

\section{DAFTAR PUSTAKA}

2005. Kanus Besar Bahasa Indonesia, Balai Pustaka, Jakarta.

2015. Pemberdayaan Masyarakat dan Sistem Kemitraan, LPB Baprida, Binuang. Tapin.

Amsyah, Zulkifli, 2005. Manajemen Sistem Informasi, Gramedia Pustaka Utama, Jakarta.

Anoraga, Pandji, 2005. Manajemen Bisnis, Salemba Empat, Jakarta.

Beryl Levinge and Jean Mulroy, 2004. A Partership Model for Public Health, Five

Variable for Productive Collaboration, Pact Publications. 120018 th Street, NW, Suite 350, Washington, DC 20036, www.pactpublications.com

Daniri, Mas Achmad, 2008. Standarisasi Tanggung Jawab Sosial Perusahaan. http:www.madani-ri.com/2008/01/17. Diakses tanggal 20 April 2014.

Hafsah, M Jafar, 2004. Kemitraan Usaha : Konsepsi dan Strategi, Pustaka Sinar Harapan, Jakarta.

Jogiyanto, 2005. Sistem Teknologi Informasi, Penerbit Andi, Yogyakarta.

Notoadmodjo, Soekidjo, 2003. Pengembangan Sumber Daya Manusia, Rineka Cipta, Yogyakarta.

Sevi Sawestri, Yoga Chandra Ditya, 2011. Prospek Pengembangan Dan Pemanfaatan

Sumber Daya Perikanan Kalimantan Selatan, Balai Penelitian Perikanan PerairanUmum, Palembang.

Yustika, Ahmad Erani, 2013. Ekonomi Kelembagaan, Paradigma, Teori, dan Kebijakan, Penerbit Erlangga, Jakarta. 